\title{
Antibody therapies for melanoma: New and emerging opportunities to activate immunity (Review)
}

\author{
SADEK MALAS, MICAELA HARRASSER, KATIE E. LACY and SOPHIA N. KARAGIANNIS \\ St. John's Institute of Dermatology, Division of Genetics and Molecular Medicine and NIHR Biomedical \\ Research Centre at Guy's and St. Thomas' Hospitals, King's College London, London SE1 9RT, UK
}

Received May 1, 2014; Accepted June 6, 2014

DOI: 10.3892/or.2014.3275

\begin{abstract}
The interface between malignant melanoma and patient immunity has long been recognised and efforts to treat this most lethal form of skin cancer by activating immune responses with cytokine, vaccine and also antibody immunotherapies have demonstrated promise in limited subsets of patients. In the present study, we discuss different antibody immunotherapy approaches evaluated in the context of melanoma, each designed to act on distinct targets and to employ different mechanisms to restrict tumour growth and spread. Monoclonal antibodies recognising melanoma-associated antigens such as CSPG4/MCSP and targeting elements of tumour-associated vasculature (VEGF) have constituted longstanding translational approaches aimed at reducing melanoma growth and metastasis. Recent insights into mechanisms of immune regulation and tumour-immune cell interactions have helped to identify checkpoint molecules on immune (CTLA4, PD-1) and tumour (PD-L1) cells as promising therapeutic targets. Checkpoint blockade with antibodies to activate immune responses and perhaps to counteract melanomaassociated immunomodulatory mechanisms led to the first clinical breakthrough in the form of an anti-CTLA4 monoclonal antibody. Novel modalities to target key mechanisms of immune suppression and to redirect potent effector cell subsets against tumours are expected to improve clinical outcomes and to provide previously unexplored avenues for therapeutic interventions.
\end{abstract}

\section{Contents}

1. Clinical landscape

2. Monoclonal antibodies

Correspondence to: Dr Sophia N. Karagiannis, St. John's Institute of Dermatology, Division of Genetics and Molecular Medicine and NIHR Biomedical Research Centre at Guy's and St. Thomas' Hospitals, King's College London, Guy's Hospital, Tower Wing, 9th Floor, London, SE1 9RT, UK

E-mail: sophia.karagiannis@kcl.ac.uk

Key words: antibodies, melanoma, immunotherapy, host immunity, immunosuppression, effector cells, cytotoxicity, checkpoint blockade
3. Examples of combination strategies with antibodies

4. Signalling pathway inhibitors: novel non-immunological treatments with immunological relevance

5. Conclusions

\section{Clinical landscape}

Malignant melanoma is responsible for $\sim 75 \%$ of all skin cancer-related deaths with 250,000 new cases diagnosed yearly worldwide. The 5-year survival rate is $\sim 95 \%$ for patients diagnosed with stage I disease and markedly falls to $<10 \%$ for patients with metastatic stage IV disease (1). Until recently, available treatments were limited. The most commonly used chemotherapeutic agent to treat patients with advanced melanoma has for many years been dacarbazine, an alkylating agent licenced in 1975 to treat unresectable stage IV disease. Dacarbazine works by inducing cell cycle arrest and tumour cell apoptosis and treatment results in a response rate of $\sim 15-20 \%$ and median response duration of $\sim 4$ months (2). Immunotherapeutic strategies in the form of the recombinant cytokines IL-2 and IFN $\alpha$, although not universally applied in standard practice due to their side-effects, support the notion that activating immunity in cancer may have a positive clinical impact (3). The recent regulatory approval of two classes of agents has transformed clinical care: the pathway inhibitor small drugs vemurafenib, dabrafenib and trametinib; and a monoclonal antibody, known as ipilimumab, that targets the $\mathrm{T}$ cell checkpoint molecule CTLA4 to promote T cell activation (Table I) (4-7).

Insights from the interplay with immune responses. Melanoma has for decades been considered an immunogenic tumour. The presence of specific immune cell subsets such as T lymphocyte infiltrates within melanoma lesions is thought to correlate with favourable patient outcomes (8). Clinical observations of partial or whole regressions of melanoma lesions, clinical evidence of spontaneous complete remissions, the increased prevalence of melanoma in immunocompromised patients and the mixed success of immune-based therapies dating back over many years, further support an important role for the tumour-immunity interface in melanoma.

Melanoma cells are thought to potentiate an inflammatory-based response constituting various cell subsets such as 
cytotoxic T cells (CTLs), dendritic cells (DCs), macrophages, neutrophils, mast cells, $\mathrm{T}$ and $\mathrm{B}$ lymphocytes and also an array of cytokines and antibodies within the tumour and systemically (9-11). However, local and systemic immunity often fails to stem cancer progression. It has been postulated that the immune system struggles to balance mounting a sufficient immune response against altered self-proteins expressed on tumours on the one hand, while aiming to avoid unwanted responses against self, on the other (12). Tumour-associated immunosuppressive components such as regulatory $\mathrm{T}$ cells (Tregs), myeloid-derived suppressor cells (MDSCs) and alternatively activated (M2d) macrophages, along with mediators such as IL-10, transforming growth factor (TGF- $\beta$ ) and vascular endothelial growth factor (VEGF) promote inflammation and immune suppression, diverting $\mathrm{T}$ and $\mathrm{B}$ cell responses and antibody expression in favour of inactive or suppressive subclasses such as IgG4 and preventing potentially cytotoxic $\mathrm{T}$ cells, DC and macrophages from launching potent antitumoural functions (13-16). Therefore, interactions between tumours and immunity are often tipped in favour of tumour growth.

The limited positive impact of standard chemotherapeutics on advanced disease survival and evidence that host immunity is capable of detecting the presence of tumours have long provided the motivation to design new therapy approaches, including those with the capacity to activate or redirect immune responses against melanoma.

Cytokine therapies. Early efforts to harness immunity focused on recombinant cytokines IFN $\alpha 2 b$ and IL-2 $(3,17)$. IL-2 was used on the basis that it could have antitumour effects by inducing expansion of tumour-specific T cell populations (18). However, treatment with high dose IL-2 for advanced disease resulted in an objective response rate of 5-27\% and complete responses of up to $4 \%$ of patients in randomised controlled trials (19). High dose treatments have serious side-effects, such as hepatic and renal toxicities and high mortality rates (Table I) (20).

IFN $\alpha$, a member of the type I-IFN family, is an antiviral and powerful pro-inflammatory cytokine produced by a wide variety of cells (including T cells, NK cells, macrophages). Shown to inhibit proliferation of B16 murine melanoma cells in vivo and in vitro, it is thought to have antitumoural effects via anti-angiogenic and pro-apoptotic functions and by enhancing tumour antigen presentation and potentiating $\mathrm{CD} 4^{+}$ $\mathrm{T}$ cell-mediated tumour cell targeting $(21,22)$. High doses of IFN $\alpha$ have been shown to prolong disease-free survival and, when used in the adjuvant setting, the agent could increase overall survival in high-risk patients (23), although treatment was not demonstrated to result in significant survival improvements when compared with chemotherapy in randomised trials. Although approved for clinical use and used in the adjuvant setting in Europe, INF $\alpha$ is not standard of care in the United Kingdom $(24,25)$. Recent investigations have shown that a modified form of IFN $\alpha$ (pegylated IFN $\alpha 2 \beta$ ) with a longer half-life in vivo has enhanced therapeutic efficacy and improved tolerability, leading to FDA approval as an adjuvant therapy in 2011 (Table I) (26).

Vaccine approaches. Vaccination strategies have been investigated using peptides, proteins, cells, DNA and viral vaccines or various forms of modified cell therapies such as adoptive DC and T cell therapies; a DC therapy is available for the treatment of prostate cancer, offering hope for similar treatments in melanoma (27). Tumour cells used as immunogens, melanoma peptide and protein recombinant antigens or DNA viral vector vaccines have been designed to stimulate different components of the immune response and these efforts continue to date (28). A recent study showed induction of immunity against metastatic melanoma through vaccination with mature DCs loaded with melanoma antigens (MART-1, MAGE-3, gp100 and tyrosinase) processed through melanoma constitutive proteasomes for presentation by MHC class I to cognate T cells. Treatment enhanced $\mathrm{Ag}$-specific $\mathrm{T}$ cell responses and reduced levels of circulating tumour cells in all patients (29). A phase I study of a murine gp100 DNA vaccine in malignant melanoma patients showed that the delivery of xenogeneic melanoma antigens (Tyr, gp100) can activate a specific CTL response to these proteins, with low associated toxicity and gp100-reactive $\mathrm{T}$ cell responses were reported in some patients, but without improving median survival (30). Although limited by their individual patient-specific nature, reliance on high expertise and high associated costs, adoptive cell strategies are now accelerated by the emergence of new technologies. To date, however, vaccines demonstrating clinical benefits have not reached clinical utility in melanoma.

\section{Monoclonal antibodies}

Antibody-based agents have been increasingly used as therapies for a wide range of human malignancies, including some solid tumour indications such as breast, colorectal and lung cancers (31). Antibodies can exert their antitumoural functions directly by specific recognition of cell surface antigen-expressing target cells, such as signalling proliferation arrest, inducing apoptosis, blocking cytokine receptor interactions to starve tumour cells of vital growth signals, or preventing tumour cell-extracellular matrix interactions to restrict migration and metastasis (Fig. 1A). Antibodies can also link target antigen expressing cells (such as tumour cells) with immune effector cells bearing Fc receptors, potentiating effector cell activation and target-neutralising functions (Fig. 1B) by engendering antibody-dependent effector cell-mediated cytotoxicity (ADCC), phagocytosis (ADCP) or complement activation (CDC). Antibodies can also be used as immunogens, to promote antigen presentation and initiate adaptive immune responses against cancer cells, or by targeting key elements of immune modulatory pathways to overcome effector cell anergy. Another function may entail targeting critical events in the tumour microenvironment, such as VEGFs to inhibit angiogenesis, restricting tumours of vital nutrient supply and/or escape of metastatic cells into the circulation (Fig. 1C).

Studies on the merits of antibody therapies for the treatment of melanoma date back a few decades, but the clinical utility of this modality has only recently been demonstrated with the approval of the first antibody in 2011. Renewed attention is now focused towards melanoma immunotherapies including monoclonal antibodies that can target key cancer pathways and activate immunity (32). Here, we discuss examples of different antibody therapeutic strategies studied for melanoma. 
Table I. Food and drug administration-approved agents for the treatment of malignant melanoma.

\begin{tabular}{|c|c|c|c|c|}
\hline $\begin{array}{l}\text { Agent } \\
\text { (brand name) }\end{array}$ & $\begin{array}{l}\text { Year of } \\
\text { approval }\end{array}$ & Specificity & Class & Mechanisms of action \\
\hline $\begin{array}{l}\text { Dacarbazine } \\
\text { (DTIC-Dome }^{\circledR} \text { ) }\end{array}$ & 1975 & Non-specific & Chemotherapy & $\begin{array}{l}\text { Alkylating agent leading to DNA } \\
\text { damage, inducing cell cycle arrest } \\
\text { and tumour cell apoptosis }\end{array}$ \\
\hline $\begin{array}{l}\text { IFN } \alpha 2 \mathrm{~b} \\
\left(\mathrm{INTRON}^{\circledR} \mathrm{A}\right)\end{array}$ & 1995 & $\begin{array}{l}\text { IFN } \alpha \text { receptor } \\
1 \text { and } 2\end{array}$ & $\begin{array}{l}\text { Immunotherapy } \\
\text { (cytokine) }\end{array}$ & $\begin{array}{l}\text { Multifunctioning immunoactivatory } \\
\text { cytokine enhances antitumoural } \\
\text { response, anti-angiogenic, } \\
\text { anti-proliferative and pro-apoptotic } \\
\text { properties }\end{array}$ \\
\hline $\begin{array}{l}\text { High dose IL-2 } \\
\text { (Aldesleukin, } \\
\text { Proleukin }^{\circledR} \text { ) }\end{array}$ & 1998 & $\begin{array}{l}\text { IL-2 receptor } \\
\text { expressed on } \\
\text { lymphocytes }\end{array}$ & $\begin{array}{l}\text { Immunotherapy } \\
\text { (cytokine) }\end{array}$ & $\begin{array}{l}\text { Immune activating, increases } \\
\text { activation and proliferation } \\
\text { of immune cells (e.g. T, NK, B cells) }\end{array}$ \\
\hline $\begin{array}{l}\text { Pegylated } \\
\text { IFN } \alpha 2 b \\
\left(\text { PEG INTRON }^{\circledR} \mathrm{A}\right)\end{array}$ & 2011 & $\begin{array}{l}\text { IFN } \alpha \text { receptor } \\
1 \text { and } 2\end{array}$ & $\begin{array}{l}\text { Immunotherapy } \\
\text { (cytokine) }\end{array}$ & $\begin{array}{l}\text { Modified (pegylated) form of } \\
\text { IFN } \alpha 2 \text { b with increased half-life and } \\
\text { enhanced therapeutic efficacy }\end{array}$ \\
\hline $\begin{array}{l}\text { Ipilimumab } \\
\left(\text { Yervoy }^{\circledR}\right)\end{array}$ & 2011 & $\begin{array}{l}\text { CTLA4 } \\
\text { expressed on } \\
\mathrm{T} \text { cells }\end{array}$ & $\begin{array}{l}\text { Immunotherapy } \\
(\mathrm{mAb})\end{array}$ & $\begin{array}{l}\text { Humanised mAb targeting the } \\
\text { inhibitory receptor CTLA4 } \\
\text { activates immune system enhancing } \\
\text { T cell activation and targeting } \\
\text { CTLA4-expressing Tregs }\end{array}$ \\
\hline $\begin{array}{l}\text { Verumafenib } \\
\left(\text { Zelboraf }^{\circledR}\right)\end{array}$ & 2011 & $\begin{array}{l}\text { BRAF V600E, } \\
\text { mutated form of } \\
\text { BRAF protein }\end{array}$ & $\begin{array}{l}\text { Small molecule } \\
\text { inhibitor }\end{array}$ & $\begin{array}{l}\text { Blocks mitogen-activated protein } \\
\text { kinase pathway reducing } \\
\text { proliferation of melanoma cells } \\
\text { carrying mutation }\end{array}$ \\
\hline $\begin{array}{l}\text { Dabrafenib } \\
\left.\text { (Tafinlar }^{\circledR}\right)\end{array}$ & 2013 & $\begin{array}{l}\text { BRAF V600E } \\
\text { mutated form of } \\
\text { BRAF protein }\end{array}$ & $\begin{array}{l}\text { Small molecule } \\
\text { inhibitor }\end{array}$ & $\begin{array}{l}\text { Blocks mitogen-activated protein } \\
\text { kinase pathway reducing } \\
\text { proliferation of melanoma cells } \\
\text { carrying mutation }\end{array}$ \\
\hline $\begin{array}{l}\text { Trametinib } \\
\left(\text { Mekinist }^{\circledR}\right)\end{array}$ & 2013 & $\begin{array}{l}\text { BRAF V600E } \\
\text { or V600K } \\
\text { mutated forms } \\
\text { of BRAF } \\
\text { protein }\end{array}$ & $\begin{array}{l}\text { Small molecule } \\
\text { inhibitor }\end{array}$ & $\begin{array}{l}\text { Blocks mitogen-activated protein } \\
\text { kinase pathway reducing } \\
\text { proliferation of melanoma cells } \\
\text { carrying mutation }\end{array}$ \\
\hline
\end{tabular}

mAb, monoclonal antibody; IFN, interferon; IL, interleukin.

Targeting cell surface antigens on tumour cells: CSPG4. A widely used approach for antibody therapies entails selective recognition of specific molecules such as proteins, sugar or lipid moieties, which are overexpressed or mutated on the surface of cancer cells. In the context of melanoma, a notable example of this strategy includes antibodies designed to recognise the tumour-associated antigen chondroitin sulphate proteoglycan 4 (CSPG4). Otherwise known as melanoma-associated chondroitin sulphate proteoglycan (MCSP) or human high molecular weight-melanoma associated antigen (HMW-MAA), CSPG4 is a 2322-residue membrane-bound protein overexpressed on $80-85 \%$ of melanoma lesions and also on a proportion of basal cell and breast carcinomas and several leukaemia types $(33,34)$.
CSPG4 is known to play roles in the adhesion, spreading and migration of melanoma cells through activation of intracellular signalling cascades such as the focal adhesion kinase (FAK), PI3K/AKT, NFאB and MAPK/ERK 1/2 pathways, promoting sustained high levels of activatory signals required for malignant progression (35-37). In addition to melanoma cells, CSPG4 is expressed at high levels in tumour angiogenic vasculature, providing the potential for a targeted therapy to also restrict tumour blood supply (38). Overexpression in melanomas at different stages, restricted tissue distribution in normal tissues and a central role in cancer cell motility, metastasis and tissue invasion, render CSPG4 an attractive therapeutic target for applications, including monoclonal antibodies that may be used in adjuvant and in advanced disease settings. 
A

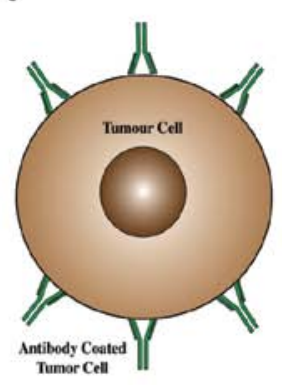

B

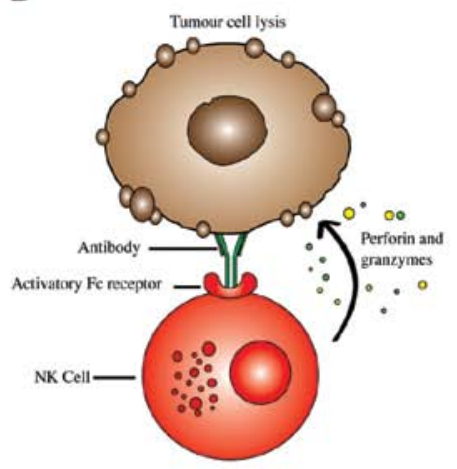

C

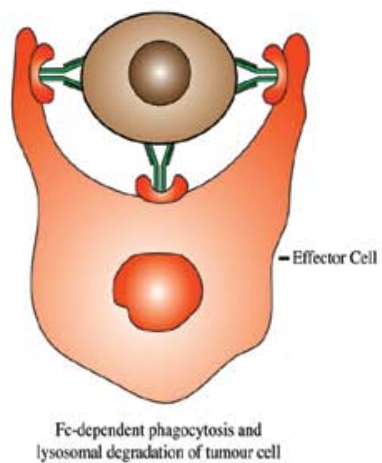

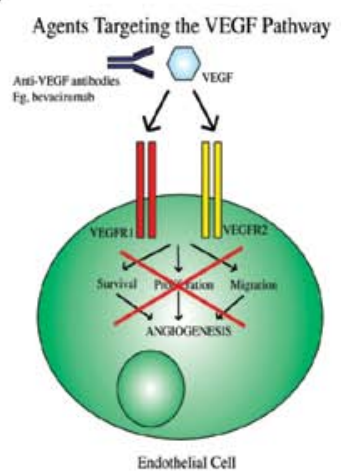

D

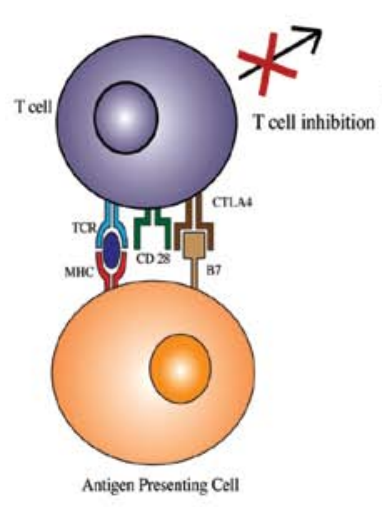

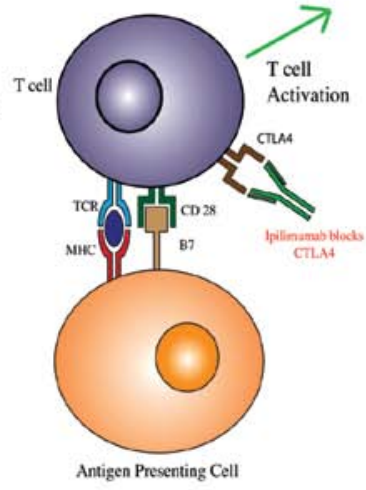

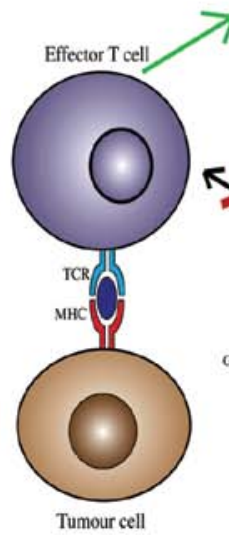

Tumour cell

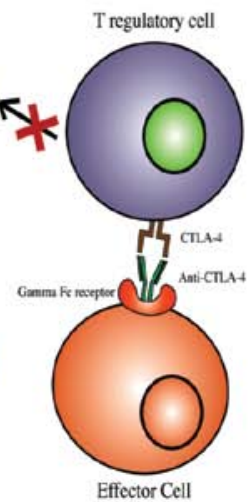

E

Figure 1. Possible mechanisms of action employed by monoclonal antibodies. (A) Direct effects by specific recognition of cell surface target antigens, triggering possible downstream signalling events that lead to target cell death. (B) Antibody-dependent cell-mediated cytotoxicity (ADCC) is based on antigen target-reactive antibodies coating tumour cells recognised by Fc receptors expressed on immune cells such as NK cells, macrophages and neutrophils; these lead to effector cell activation and tumour cell death (left). Antibody-coated tumour cells can also engage Fc receptors present on phagocytes leading to antibody-dependent cell-mediated phagocytosis (ADCP) (right) of the target cell. (C) Targeting VEGF prevents its association with its cell surface receptors (VEGFR1, VEGFR2) preventing downstream signals that lead to formation of tumour-associated vasculature. (D) Targeting the checkpoint molecule CTLA4; CTLA4 binds to B7 on antigen presenting cells (APC) and interferes with CD28-B7 complex co-stimulatory signals needed for MHC-antigen-TCR antigen presentation, thus inhibiting T cell activation. Antibodies such as ipilimumab block binding of CTLA4 to B7 on the surface of APCs; this allows CD28-B7 complex assembly and co-stimulation that restores T cell activation. Ipilimumab also activates Fc receptor-expressing effector cells against CTLA4-expressing Tregs, leading to their elimination via ADCC. (E) Targeting the PD-1:PD-L1 interactions with antibodies: PD-1 on the surface of antigen-educated T cells engages with PD-L1 expressed on melanoma cells and on other immune cells in tumours, leading to T cell anergy and/or deletion. PD-1:PD-L1 complex formation may play a role in tumour immune escape and antibodies targeting the PD-1/PD-L1 blockade may activate T cell responses against melanoma.

Monoclonal antibodies and antibody fragments have been examined with the view to develop targeted therapies against CSPG4-expressing tumours. Antibodies conjugated to radioisotopes or toxins (purothionin, pseudomonas exotoxin A, methotrexate) could induce tumour cell clearance by antibody-targeted delivery of these moieties to melanoma cells. Another early approach aimed at overcoming immunological unresponsiveness to CSPG4 entailed designing anti-idiotypic antibodies to act as immunogens by mimicking tumour antigen epitopes known to be recognised by patient humoral responses. Early clinical trials reported the development of anti-CSPG4 antibodies associated with prolonged survival of melanoma patients who responded to antibody therapy (39-43). Host anti-CSPG4 antibodies were detected in $~ 60 \%$ of patients after treatment with an anti-idiotypic antibody in conjunction with an adjuvant (BCG) and those individuals who developed antibodies also showed longer median survival (42-44).
A humanised bi-specific BiTE antibody (bi-specific T-cell engaging), able to bind both CSPG4 and human CD3 to engage the T cell receptor (TCR) complex, was designed to redirect $\mathrm{CD}^{+} \mathrm{T}$ cells (especially $\mathrm{CTL}$ ) against melanoma cells (45). This strategy aimed at triggering $\mathrm{T}$ cell activation in the absence of specific $\mathrm{T}$ cell clones or antigen presentation by APC. When peripheral blood mononuclear cells (PMBCs) from healthy donors co-cultured with melanoma cells were treated with MCSP-BiTE antibodies at different doses, PBMCs lysed CSPG4-expressing melanoma cells in an antigen-specific manner. Notably, similar cytotoxic activity was observed with $\mathrm{T}$ cells from melanoma patients, although the proportions of $\mathrm{CD}^{+} \mathrm{T}$ cells in patient blood were lower compared to those from healthy volunteers.

An anti-CSPG4 scFv antibody fragment fused with human TRAIL (TNF-related apoptosis-inducing ligand) was designed to deliver pro-apoptotic TRAIL-signalling activity when bound to $\mathrm{CSPG}^{+}$melanoma cells, while inhibiting 
antitumourigenic signalling via CSPG4 downstream signal blocking. Previous studies showed the inhibition of $\mathrm{CSPG}^{+}$ melanoma cells in vitro and in vivo with this agent and reported that antitumoural activity was enhanced in the presence of the sigma receptor $(\sigma \mathrm{R})$ rimcazole, also known to have selective antitumoural activity $(46,47)$. A more recent approach entails engineered T cells with a CSPG4-specific chimaeric antigen receptor also encoding the $\mathrm{CD} 28$ co-stimulatory endodomain. CAR-CSPG4-expressing T cells demonstrated antitumoural activities in vitro and in mouse models of melanoma, mesothelioma, breast and head and neck squamous cell carcinomas (48). Several years of promising findings with a variety of approaches based on CSPG4 as a tumour target, together with recent technical, translational and clinical developments in the field of antibody therapeutics for solid tumours, now provide a strong case for revisiting the concept of an antibody modality centred on this promising tumour antigen.

Targeting tumour vasculature: VEGF. Malignant melanoma progression from the radial to the vertical growth phases has been associated with increased microvessel density and poorer outcomes for patients with high tumour-associated vasculature. Melanoma tumours feature increased production of pro-angiogenic factors such as the VEGF family molecules, VEGF-A involved in angiogenesis, VEGF-B associated with embryonic angiogenesis, VEGF-C with known roles in lymphangiogenesis, VEGF-D participating in lung bronchiole lymphatic vasculature, and VEGF-E encoded from a gene of viral origin with endothelial cell proliferative properties. Production of VEGFs, especially VEGF-A, VEGF-C and VEGF-D, and their receptors VEGFR-1, VEGFR-2 and VEGFR-3 trigger changes in endothelial cell proliferation, support formation of de novo blood vessels and vascular permeability at different tumour sites, to allow a higher degree of tumour cell survival and distal metastases. During tumour growth, VEGF-A, overexpressed in many solid tumours including melanoma, can stimulate a hypoxia-driven cascade of endothelial cell proliferation and migration leading to angiogenesis via recognition of the class III tyrosine kinase receptors (VEGFR-1 and 2) (49,50). Melanoma lymph node metastases involve higher expression and engagement of the VEGF-C/D and VEGFR-3 system.

The hypothesis that blocking VEGF-VEGFR interactions may be beneficial for patients led to the development of bevacizumab, a humanised monoclonal antibody recognising a high affinity epitope expressed on all VEGF-A isoforms. The antibody blocks VEGF binding to both receptors (Fig. 1C) $(51,52)$ and has been approved by FDA for the first-line treatment of metastatic colorectal and breast cancers. A phase II study of this antibody as a first-line treatment for metastatic melanoma, in combination with the cytotoxic nitrosourea alkylating agent fotemustine, significantly reduced systemic levels of VEGF-A and VEGF-C, and also of the receptors VEGFR-1 and VEGFR-2. These findings suggested that this therapy contributes to the inhibition of angiogenesis and lymphangiogenesis, both of which are highly relevant in the context of melanoma progression (53). The mean time to progression was reported to be 8 months and overall survival was 20.5 months in previously untreated patients with advanced disease. Other trials, such as a phase II trial testing bevacizumab in combination with low dose IFN- $\alpha 2$ b or standard chemotherapy, showed low activity and general minimal toxicity in addition to a stable disease state prolonged in some patients $(54,55)$. The adjuvant avastin trial in high-risk melanoma (AVAST-M) sponsored by Cancer Research UK, a large phase III study for patients with stage IIB, IIC and III cutaneous melanoma following resection aimed to evaluate the capacity of bevacizumab to prevent disease recurrence in the adjuvant setting, when early angiogenesis may be prevented from assisting formation of early metastases. Results from the AVAST-M trial demonstrated good tolerability but noted no significant differences in the overall survival between treatment and observation groups (56). Other approaches may include antibodies directly targeting VEGF receptors (e.g. combinations of antibodies such as bevacizumab with chemotherapies or immunotherapies (57-59).

Focus on $T$ cell checkpoint cascades: CTLA4. The cytotoxic T-lymphocyte antigen-4, CTLA4, expressed on the surface of activated $\mathrm{T}$ lymphocytes, acts as an inhibitory molecule of $\mathrm{T}$ cell activation by competing with $\mathrm{CD} 28$ for binding to the co-stimulatory B7 family members on antigen-presenting cells $(60,61)$. This leads to inhibition of TCR activity, reducing IL-2 gene transcription and T cell proliferation. CTLA4 acts as a negative regulator of $\mathrm{T}$ cell activation, contributing to antigen tolerance and limiting $\mathrm{T}$ cell mediated autoimmunity and homeostasis maintenance. Since tumour antigens are largely self-antigens, it was hypothesised that blocking CTLA4-B7 interactions to enhance $\mathrm{T}$ cell activation could help overcome tumour antigen tolerance and consequently potentiate enhanced antitumoural immune responses.

Ipilimumab, a human IgG1 antibody recognising CTLA4, interferes with CTLA4-B7 interactions on the surface of antigen presenting cells, permitting CD28-B7 complex formation. The antibody has been shown to operate by reducing CTLA4-induced $\mathrm{T}$ cell inhibitory functions, but also by targeting activatory $\mathrm{Fc}$ receptor-expressing effector cells against CTLA4-expressing Tregs, thereby blocking their immunosuppressive functions in tumours (Fig. 1D) (62-64). In early clinical studies, this agent showed adequate safety and an indication of efficacy, leading to subsequent trials at the National Cancer Institute (USA) that demonstrated sustained responses ( $>2$ years) in a proportion of patients. Grade 3 or 4 adverse events such as colitis, rash and liver function abnormalities were observed in $19 \%$ of patients. A randomised, multi-institution, double blind, dose-ranging clinical study showed encouraging results with response rates as high as $11.1 \%$ and survival data as high as $30 \%$ (65-67). Combination studies of administration of ipilimumab with dacarbazine indicated increased response rates with combination treatment when compared with single treatment controls $(68,69)$. A phase III trial was the first randomised study to show a survival benefit in patients with metastatic melanoma: ipilimumab $(3 \mathrm{mg} / \mathrm{kg}$ dose) demonstrated median overall survival of 10 months and 10.1 months when combined with an HLA-A*0201-restricted gp100 vaccine peptide, while gp100 peptide treatment alone showed a median overall survival of 6.4 months (70).

Ipilimumab (at $3 \mathrm{mg} / \mathrm{kg}$ once every three weeks for four times) was the first antibody to be approved in 2011 by the FDA in the USA and soon afterwards in Europe for the treatment of patients with unresectable or metastatic melanoma (stage III 
and IV disease) (Table I) (71). This was a significant milestone as this was the first antibody to demonstrate significant survival benefits in patients with advanced melanoma (72). In clinical application, $\sim 40 \%$ of patients experience immune-related adverse events (irAEs) through the universal activation of $\mathrm{T}$ cells, leading to tissue-specific inflammation and autoimmunerelated side-effects, such as dermatitis, colitis and hepatitis. These side-effects can be managed with systemic steroid treatments without significant effects on benefit from the antibody therapy, but highlight the need for careful patient selection in addition to frequent monitoring. Comprehensive toxicity management algorithms have been developed to help manage patients, especially as most of the toxicities are reversible with early intervention. It is noteworthy that patients who experience autoimmune-related adverse events are more likely to benefit from treatment with ipilimumab, pointing to a fine balance between autoimmunity and the clearance of tumours (73).

Tremelimumab, a human IgG2 anti-CTLA4 monoclonal antibody, was also examined. Although it demonstrated durable objective tumour regressions in early clinical trials, it was less effective than ipilimumab, with lower response rates and median survival and a phase III study indicated no superior benefits relative to those observed with dacarbazine (74).

Although ipilimumab is the only antibody therapy to date that has shown significant impact on overall survival in advanced melanoma, ongoing late phase clinical trials are presently exploring anti-CTLA4 antibodies alone or in combination with other antibodies, immunotherapies and chemotherapeutic agents (Tables I and II).

The PD-1/PD-L1 axis. Programmed death-1 (PD-1, CD279, or B7-H1), a member of the B7:CD28 group of cell surface molecules with homology to CTLA4, is an inhibitory cell surface protein expressed on the surface of mature, antigen-experienced $\mathrm{T}$ and $\mathrm{B}$ lymphocytes and myeloid cells following activation. Its ligand, PD-L1, is upregulated on the surface of antigen presenting cells in addition to epithelial cells and vascular endothelial cells upon antigenic stimulation with inflammatory signals such as IFN $\gamma$. PD-L1 has also been shown to be expressed on melanoma cells and other immune cells in tumours. Engagement of PD-1 to PD-L1 can inhibit $\mathrm{T}$ cell growth and cytokine secretion. PD-1 may play a critical role in tumour immune escape by engaging with PD-L1 and negatively regulating both cellular and humoral immune responses, permitting tumours to evade immune surveillance. PD-1 and PD-L1 expression is also linked to poor clinical prognosis. Therefore, blocking their interactions has been investigated as a possible immunotherapy strategy (Fig. 1E) (75-77).

A phase I clinical trial of the human IgG4 antibody nivolumab (MDX-1106) recognising PD-1 in melanoma (among other refractory cancers) has shown encouraging clinical activity and safety profiles (78). Nivolumab was also recently tested in further clinical studies, with reported median overall survival of 16.8 months, $62 \%$ 1-year and $43 \%$ 2-year survival rates. Grade 3 and 4 toxicities were found in only $5 \%$ of patients and clinical responses persisted even after cessation of therapy $(79,80)$. A recent study showed that treatment with another anti-PD-1 humanised IgG4 antibody lambrolizumab in patients with advanced melanoma led to a tumour regression response rate of $38 \%$ (according to the response evaluation criteria in solid tumours, RECIST), with a durable effect and a median progression-free survival $>7$ months. Common, mostly low grade adverse effects observed during the treatment were fatigue, pruritus and rash (81).

Antibodies targeting PD-L1 found to be upregulated on tumour cells and on tumour-associated APCs triggered a high level of infiltrating $\mathrm{T}$ cells within tumour environments. A fully-human IgG4 antibody to PD-L1 that blocks association with PD-1 as well as with CD80 was tested in early clinical studies in different solid tumours including melanoma. Objective responses were observed in a proportion of patients with melanoma and durable responses were reported in a small proportion of patients (82). Any therapeutic effects of the PD-1/PD-L1 blockade continue to be examined in ongoing experimental and clinical studies.

Depleting Tregs: anti-CD25. Tregs are considered a key suppressive cell subset which has high relevance in modulated antitumour responses. It has been suggested that Tregs may be partly responsible for the limited efficacy of adjuvant immunotherapies and vaccines (83). Tregs have been identified in primary melanomas, different metastatic sites and lymph nodes with melanoma cell metastases, and higher densities of Tregs correlate with thicker primary melanomas in the vertical growth phase $(84,85)$. Increased numbers of skin resident Tregs are also observed in the skin of older people, indicating that increased age may entail less effective immune activation (86). Studies on tumour models suggest a link between Treg depletion and enhanced antitumour immunity. Targeting this cell subset has therefore been considered as a potential strategy to enhance the potency of immunotherapies. Daclizumab, a human anti-CD25 antibody was found to be successful in deleting circulating Tregs in patients with melanoma; however, depletion did not enhance the efficacy of a DC vaccine (87). An important limitation is that CD25 is not exclusively expressed by Tregs, but is also expressed on other activated $\mathrm{T}$ cell subsets, with potential harmful consequences associated with an anti-CD25 targeted therapy in weakening other crucial components of immunity.

\section{Examples of combination strategies with antibodies}

Combination of anti-CTLA4 and anti-PD-1. Another approach is based on combining the blockade of both CTLA4 and PD-1 with antibodies. This strategy resulted in reduced Treg density in addition to enhanced effector $\mathrm{T}$ cell infiltration in tumour lesions in a mouse melanoma model (88). The concept was recently examined in a phase I clinical trial, administering nivolumab (IgG4 antibody to PD-1) and ipilimumab (IgG1 antibody to CTLA4) in patients with stage III or IV melanoma. Different regimens were used: concurrent (both mAbs, followed bynivolumab alone and subsequent combined treatments), while patients pre-treated with ipilimumab were administered nivolumab (sequenced). A 2.5 year follow-up showed 53\% objective responses in the concurrent treatment group with marked tumour reductions (the majority showing a tumour regression of $\geq 80 \%$ ) compared to $20 \%$ objective response (OR) rate for sequenced treatments. Over half of patients administered concurrent treatments showed 
Table II. USA-registered phase III clinical trials of antibody therapies for melanoma. ${ }^{\mathrm{a}}$

\begin{tabular}{|c|c|c|c|c|}
\hline $\begin{array}{l}\text { Drug/ } \\
\text { intervention }\end{array}$ & Drug type & $\begin{array}{l}\text { Sequence of drug } \\
\text { administration }\end{array}$ & $\begin{array}{l}\text { Stage/cancer } \\
\text { type }\end{array}$ & Identifier \\
\hline $\begin{array}{l}\text { Ipilimumab (i) } \\
\text { vs. } \\
\text { MD-1379 (ii) } \\
\text { vs. } \\
\text { Ipilimumab (i) } \\
\text { + MD-1379 (ii) }\end{array}$ & $\begin{array}{l}\text { Anti-CTLA4 } \\
\text { monoclonal } \\
\text { antibody (i) } \\
\text { melanoma } \\
\text { peptide } \\
\text { vaccine (ii) }\end{array}$ & $\begin{array}{l}\text { IV ipilimumab every } 3 \text { weeks } \\
\text { for } 4 \text { doses } \\
\text { MDX-1379 } 2 \mathrm{ml} \text { ( } 2 \text { subcutaneous } \\
\text { injections of } 2 \mathrm{ml} \text { each, } 1 \text { to } \\
\text { each thigh), every } 3 \text { weeks } \\
\text { for } 4 \text { doses }\end{array}$ & $\begin{array}{l}\text { Unresectable } \\
\text { or metastatic } \\
\text { melanoma }\end{array}$ & NCT00094653 \\
\hline $\begin{array}{l}\text { Ipilimumab (i) } \\
\text { vs. } \\
\text { recombinant } \\
\text { IFN } \alpha 2 \text { b (ii) }\end{array}$ & $\begin{array}{l}\text { Anti-CTLA4 } \\
\text { monoclonal } \\
\text { antibody (i) } \\
\text { IFN } \alpha 2 b \text { (ii) }\end{array}$ & $\begin{array}{l}\text { High dose ipililmumab IV over } \\
90 \text { min every } 21 \text { days for } 4 \text { courses. } \\
\text { Then maintenance high-dose } \\
\text { ipilimumab IV over } 90 \text { min } \\
\text { every } 90 \text { days for a maximum } \\
\text { of } 4 \text { courses } \\
\text { High dose recombinant IFN } \alpha 2 \text { b IV } \\
\text { on days } 1-5,8-12,15-19 \text { and } 22-26 \\
\text { then maintenance high dose on } \\
\text { days } 1,3 \text { and } 5\end{array}$ & $\begin{array}{l}\text { Resected } \\
\text { high-risk } \\
\text { melanoma }\end{array}$ & NCT01274338 \\
\hline $\begin{array}{l}\text { CP-675, } 206 \text { (i) } \\
\text { vs. } \\
\text { Dacarbazine } \\
\text { (ii) or } \\
\text { Tremozolomide } \\
\text { (iii) }\end{array}$ & $\begin{array}{l}\text { Anti-CTLA4 } \\
\text { human } \\
\text { monoclonal } \\
\text { antibody (i) } \\
\text { alkylating } \\
\text { chemotherapy } \\
\text { agent (ii \& iii) }\end{array}$ & $\begin{array}{l}\text { CP- } 675,20615 \mathrm{mg} / \mathrm{kg} \text { IV Q } \\
90 \text { days x } 4 \\
\text { Dacarbazine } 1,000 \mathrm{mg} / \mathrm{kg} \\
\text { IV Q } 90 \text { days x } 4 \\
\text { Temozolomide } 200 \mathrm{mg} / \mathrm{m}^{2} \text { orally } \\
\text { on days } 1-5 \text { every } 28 \text { days x } 12\end{array}$ & $\begin{array}{l}\text { Advanced } \\
\text { melanoma }\end{array}$ & NCT00257205 \\
\hline $\begin{array}{l}\text { Ipilimumab (i) } \\
\text { vs. } \\
\text { placebo }\end{array}$ & $\begin{array}{l}\text { Anti-CTLA4 } \\
\text { monoclonal } \\
\text { antibody (ii) } \\
\text { placebo (ii) }\end{array}$ & $\begin{array}{l}\text { IV ipilimumab every } 21 \text { days for } \\
4 \text { doses, then starting from week } \\
24 \text { every } 12 \text { weeks until week } 156 \\
\text { or progression } \\
\text { IV placebo } 4 \text { x every } 21 \text { days } \\
\text { then starting from week } 24 \\
\text { every } 12 \text { weeks until week } 156 \\
\text { or progression }\end{array}$ & $\begin{array}{l}\text { High-risk } \\
\text { melanoma }\end{array}$ & NCT00636168 \\
\hline $\begin{array}{l}\text { Nivolumab (i) } \\
\text { vs. } \\
\text { Nivolumab (i) } \\
\text { + Ipilimumab } \\
\text { (ii) vs. } \\
\text { Ipilimumab (ii) }\end{array}$ & $\begin{array}{l}\text { Anti-PD-1 } \\
\text { monoclonal } \\
\text { antibody (i) } \\
\text { anti-CTLA4 } \\
\text { monoclonal } \\
\text { antibody (ii) }\end{array}$ & $\begin{array}{l}\text { IV nivolumab every } 2 \text { weeks } \\
\text { IV nivolumab with IV ipilimumab } \\
\text { every } 3 \text { weeks for } 4 \text { doses then } \\
\text { nivolumab IV every } 2 \text { weeks. } \\
\text { IV ipilimumab every } 3 \text { weeks } \\
\text { for a total of } 4 \text { doses }\end{array}$ & $\begin{array}{l}\text { Untreated } \\
\text { advanced } \\
\text { melanoma }\end{array}$ & NCT01844505 \\
\hline
\end{tabular}

${ }^{a}$ Source, www.clinicaltrials.gov. IFN $\alpha 2 b$, interferon $\alpha 2 b$.

grade 3 and 4 toxicities (89). Thus, important advantages of this combination therapy were response durability and the increased proportion of patients experiencing responses, compared to monotherapies; further late phase clinical trials are now examining this concept (Tables II and III).

Combination of $m A b$ and vaccines. Combining $\mathrm{mAb}$ and vaccines comprising long-peptides of known melanoma- or melanocyte-associated antigens, such as gp100 and the tumour-differentiation antigens tyrosinase-related proteins (TRP)-1 and TRP-2 has been studied. In a melanoma mouse model, the altered long-peptide gp10025-33 vaccine together with the TLR7 ligand imiquimod (to activate gp100-specific CTL responses), and the mAb TA99 (specific for the melanocyte protein TRP-1) were used in combination (90). This led to activation of tissue-resident $\mathrm{Fc} \gamma \mathrm{R}^{+}$immune cells (e.g. macrophages), creating a critical window of time that allowed development of peptide vaccine-induced $\mathrm{T}$ cell responses. 
Table III. European- and UK-registered phase III clinical trials of antibody therapies for melanoma. ${ }^{a}$

\begin{tabular}{|c|c|c|c|}
\hline Drug/intervention & Drug type & Stage/cancer type & Identifier \\
\hline $\begin{array}{l}\text { MK-3475 (i) } \\
\text { vs. } \\
\text { Ipilimumab (ii) }\end{array}$ & $\begin{array}{l}\text { Anti-PD-1 monoclonal } \\
\text { antibody (i) } \\
\text { anti-CTLA4 monoclonal } \\
\text { antibody (ii) }\end{array}$ & Advanced melanoma & 2012-004907-10 (EU) \\
\hline $\begin{array}{l}\text { Response and/or toxicity } \\
\text { vs. } \\
\text { Ipilimumab (i) }\end{array}$ & $\begin{array}{l}\text { Anti-CTLA4 monoclonal } \\
\text { antibody (i) }\end{array}$ & $\begin{array}{l}\text { Unresectable stage III or } \\
\text { IV malignant melanoma }\end{array}$ & 2005-002126-64 (EU) \\
\hline $\begin{array}{l}\text { Nivolumab (i) } \\
\text { vs. } \\
\text { investigator's choice }\end{array}$ & $\begin{array}{l}\text { Anti-PD-1 monoclonal } \\
\text { antibody (i) }\end{array}$ & $\begin{array}{l}\text { Unresectable or } \\
\text { metastatic melanoma } \\
\text { progressing post } \\
\text { anti-CTLA4 therapy }\end{array}$ & $\begin{array}{l}13396 \text { (UKCRN ID) } \\
\text { (UK) }\end{array}$ \\
\hline $\begin{array}{l}\text { Nivolumab (i) } \\
\text { vs. } \\
\text { Ipilimumab (ii) } \\
\text { vs. } \\
\text { Nivolumab (i) + } \\
\text { Ipilimumab (ii) }\end{array}$ & $\begin{array}{l}\text { Anti-PD-1 monoclonal } \\
\text { antibody (i) } \\
\text { anti-CTLA4 monoclonal } \\
\text { antibody (ii) }\end{array}$ & $\begin{array}{l}\text { Unresectable or } \\
\text { metastatic melanoma }\end{array}$ & $\begin{array}{l}14725 \text { (UKCRN ID) } \\
\text { (UK) }\end{array}$ \\
\hline
\end{tabular}

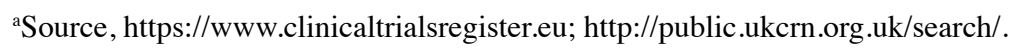

Delayed tumour growth and long-term survival responses were observed in $>50 \%$ of the treated animals.

Combination of anti-GD2, agonist $C D 40 \mathrm{mAbs}$ and $C p G$. A combination of two monoclonal antibodies and a TLR9 ligand was examined. One antibody targeted the tumour antigen disialoganglioside-GD2, a glycosphingolipid overexpressed in neuroblastoma and melanoma. This antibody was engineered with reduced complement-dependent toxicity and improved ADCC functions. The second antibody was agonistic to CD40, a member of the TNF-receptor superfamily expressed on several cells such as DCs and macrophages. By targeting CD40, the antibody promoted tumour cell apoptosis, activated DC and macrophage activation and maturation. The antibodies were administered with the TLR9 ligand class B CpG ODN 1826 recognised by B cells, DCs and NK cells to enhance innate cell responses. This combination immunotherapy was more efficacious than single therapies in a model of GD2-expressing B16 melanoma at minimum tumour burden (91). Specifically, peritoneal macrophages from mice treated with anti-CD40 antibody and $\mathrm{CpG}$ were able to inhibit tumour cell proliferation in vitro and suggested a potential role in vivo in an antigen-dependent manner. Moreover, the antitumour efficacy of anti-GD2 in vivo was increased by anti-CD40 plus CpG therapy combinations.

\section{Signalling pathway inhibitors: novel non-immunological treatments with immunological relevance}

A proportion $(\sim 60 \%)$ of melanomas harbour mutations in the serine-threonine kinase BRAF, resulting in constitutive activation of the RAS/RAF/MEK/ERK pathway and irregular cell proliferation. The most common mutations (90\%) involve a valine instead of a glutamic acid in the amino acid position 600, termed V600E mutation (92). Vemurafenib is licenced for patients whose tumours express the mutant form of the BRAF gene. This treatment has markedly greater response rates, overall survival rates and progression-free survival than dacarbazine, but most patients develop resistance and experience disease relapse (93). The BRAF inhibitors vemurafenib and dabrafenib, both selectively recognising mutant forms of BRAF, are now approved for clinical use for advanced stage disease (94).

Individually, ipilimumab and BRAF inhibitors improve overall survival and each has different clinical profiles; BRAF inhibition can result in quick but mostly temporary clinical responses, with median progression usually $<7$ months, whereas ipilimumab has a slow onset and a low rate of objective, but patients who respond to treatment experience long-lasting responses. It has also emerged that BRAF-inhibitors may improve antigen presentation and have been associated with reduced immunomodulatory responses and activated tumour-reactive $\mathrm{T}$ cells while patients respond to therapy $(95,96)$. Thus, suggestions to combine an oncogene directed therapy with immunotherapy triggered substantial interest (97). Ribas et al conducted a Phase I study aiming to evaluate the safety and the best administration schedule for patients with metastatic BRAF V600-mutant melanoma. After treatment with both agents at the full approved doses (starting with vemurafenib for one month, then ipilimumab and concurrent vemurafenib), a few patients developed toxic effects such as increased aminotransferase levels and hepatic adverse events, both asymptomatic and reversible through administration of glucocorticoids or temporary termination of the therapy. These toxicities resulted in study closure (98). 
However, ongoing clinical trials continue to examine different strategies based on this concept.

\section{Conclusions}

Melanoma has historically been considered an immunogenic malignancy and has for long been resistant to standard treatments. Antibodies have always constituted a promising modality; however, with the development of checkpoint blockade antibodies and the approval of the first antibody for clinical use, their capacity to transform the treatment of patients is now better appreciated. Momentum is now gathering in the search for agents with capacity to potentiate immune clearance of melanoma tumours and to achieve tangible survival benefits (99). Parallel to the success of antibody therapies, pathway inhibitor drugs are also making a positive impact on disease management, despite drug resistance developing in most patients within months of treatment.

Beyond clinical application of checkpoint blocking antibodies, limitations of associated high toxicities and palpable clinical benefits for only a proportion of patients, immunotherapy of melanoma with antibodies now commands fresh consideration. The next generation of antibodies may be designed to re-educate and direct potent immune cells specifically against cancer cells. If achieved, a new class of agents may realize the capabilities of this modality to harness and potentially combine affinity and specificity for targets with directing potent subsets of immune effector cells against specific pathways or factors linked to cancer. Targeting inhibitory receptors such as PD-1 and PD-L1, to target tissue-resident antigen-educated $\mathrm{T}$ cell responses is likely to yield clinical data in the near future, and promises to potentiate $\mathrm{T}$ cell activation with potentially fewer toxic side-effects. Focus has also centred on combinations of antibodies with targeted pathway inhibitor drugs, other antibodies, vaccines or radiotherapy.

Yet to be explored in melanoma are emerging developments in antibody engineering including: bi-specific antibodies, including those combining tumour and immunological targets such as CD3 to focus T cells against tumours; toxin- or cytokine-loaded antibodies; modified antibodies with engineered Fc regions to enhance activatory effector functions (100). Numerous studies by us and others point towards consideration of antibodies of classes such as $\operatorname{IgA}$ or IgE with tissue immune surveillance functions that may be well-suited to the phenotypes of tumour-resident effector cells (101-107). Future studies may also provide further insights into the pathways associated with immune cell activation and re-direction in patient circulation and tumour microenvironments $(11,14,15,62,108)$. Recent studies suggest the presence of an inflammatory B cell infiltrate in melanoma and biased production of IgG4, an antibody subclass with inefficient effector activities and with capacity to block cytotoxic antibodies from attacking tumours $(10,11,14,15,109,110)$. New understanding of immunological mechanisms of response and strategies to counteract immunosuppression in melanoma may lead to new therapeutic interventions, but may also help identify predictive biomarkers for patient stratification or for monitoring responses to treatments (111). Clinically meaningful advances in the treatment of this challenging disease may now be in sight.

\section{Acknowledgements}

The authors acknowledge support from Cancer Research UK (C30122/A11527); KCL Experimental Cancer Medicine Centre, jointly funded by Cancer Research UK, the National Institute for Health Research, Welsh Assembly Government, HSC R\&D Office for Northern Ireland and Chief Scientist Office, Scotland (C10355/A15587); CR UK/EPSRC/MRC/NIHR KCL/UCL Comprehensive Cancer Imaging Centre (C1519/A10331); The British Skin Foundation (S633); Academy of Medical Sciences; Dermatrust. The research was supported by the National Institute for Health Research (NIHR) Biomedical Research Centre based at Guy's and St Thomas' NHS Foundation Trust and King's College London. The views expressed are those of the author(s) and not necessarily those of the NHS, the NIHR or the Department of Health.

\section{References}

1. Balch CM, Gershenwald JE, Soong SJ, et al: Final version of 2009 AJCC melanoma staging and classification. J Clin Oncol 27: 6199-6206, 2009.

2. Gerner RE, Moore GE and Dickey C: Combination chemotherapy in disseminated melanoma and other solid tumors in adults. Oncology 31: 22-30, 1975.

3. Atkins MB: Cytokine-based therapy and biochemotherapy for advanced melanoma. Clin Cancer Res 12: 2353s-2358s, 2006.

4. Ballantyne AD and Garnock-Jones KP: Dabrafenib: first global approval. Drugs 73: 1367-1376, 2013.

5. Bollag G, Tsai J, Zhang J, et al: Vemurafenib: the first drug approved for BRAF-mutant cancer. Nat Rev Drug Discov 11: 873-886, 2012.

6. Wright CJ and McCormack PL: Trametinib: first global approval. Drugs 73: 1245-1254, 2013.

7. Sznol M: Advances in the treatment of metastatic melanoma: new immunomodulatory agents. Semin Oncol 39: 192-203, 2012.

8. Oble DA, Loewe R, Yu P and Mihm MC Jr: Focus on TILs: prognostic significance of tumor infiltrating lymphocytes in human melanoma. Cancer Immun 9: 3, 2009.

9. Shimanovsky A, Jethava A and Dasanu CA: Immune alterations in malignant melanoma and current immunotherapy concepts. Expert Opin Biol Ther 13: 1413-1427, 2013.

10. Cipponi A, Mercier M, Seremet T, et al: Neogenesis of lymphoid structures and antibody responses occur in human melanoma metastases. Cancer Res 72: 3997-4007, 2012.

11. Gilbert AE, Karagiannis P, Dodev T, et al: Monitoring the systemic human memory B cell compartment of melanoma patients for anti-tumor IgG antibodies. PLoS One 6: e19330, 2011.

12. Lacy KE, Karagiannis SN and Nestle FO: Advances in the treatment of melanoma. Clin Med 12: 168-171, 2012.

13. Fujimura T, Ring S, Umansky V, Mahnke K and Enk AH: Regulatory T cells stimulate B7-H1 expression in myeloid-derived suppressor cells in ret melanomas. J Invest Dermatol 132: 1239-1246, 2012.

14. Karagiannis P, Gilbert AE, Nestle FO and Karagiannis SN: IgG4 antibodies and cancer-associated inflammation: insights into a novel mechanism of immune escape. Oncoimmunology 2: e24889, 2013.

15. Karagiannis P, Gilbert AE, Josephs DH, et al: IgG4 subclass antibodies impair antitumor immunity in melanoma. J Clin Invest 123: 1457-1474, 2013.

16. Wang T, Ge Y, Xiao M, et al: Melanoma-derived conditioned media efficiently induce the differentiation of monocytes to macrophages that display a highly invasive gene signature. Pigment Cell Melanoma Res 25: 493-505, 2012.

17. Atkins MB, Lotze MT, Dutcher JP, et al: High-dose recombinant interleukin 2 therapy for patients with metastatic melanoma: analysis of 270 patients treated between 1985 and 1993. J Clin Oncol 17: 2105-2116, 1999.

18. Hauschild A: Adjuvant interferon alfa for melanoma: new evidence-based treatment recommendations? Curr Oncol 16: 3-6, 2009. 
19. Petrella T, Quirt I, Verma S, Haynes AE, Charette M, Bak K, et al Single-agent interleukin-2 in the treatment of metastatic melanoma: a systematic review. Cancer Treat Rev 33: 484-496, 2007.

20. Sasse AD, Sasse EC, Clark LG, Ulloa L and Clark OA: Chemoimmunotherapy versus chemotherapy for metastatic malignant melanoma. Cochrane Database Syst Rev: CD005413, 2007.

21. Borden EC: Interferons: pleiotropic cellular modulators. Clin Immunol Immunopathol 62: S18-24, 1992.

22. Bart RS, Porzio NR, Kopf AW, Vilcek JT, Cheng EH and Farcet Y: Inhibition of growth of B16 murine malignant melanoma by exogenous interferon. Cancer Res 40: 614-619, 1980

23. Kirkwood JM, Strawderman MH, Ernstoff MS, Smith TJ, Borden EC and Blum RH: Interferon alfa-2b adjuvant therapy of high-risk resected cutaneous melanoma: the Eastern Cooperative Oncology Group Trial EST 1684. J Clin Oncol 14: 7-17, 1996.

24. Wheatley K, Ives N, Hancock B, Gore M, Eggermont A and Suciu S: Does adjuvant interferon-alpha for high-risk melanoma provide a worthwhile benefit? A meta-analysis of the randomised trials. Cancer Treat Rev 29: 241-252, 2003.

25. Hillner BE: Cost-effectiveness assessment of interferon alfa-2b as adjuvant therapy of high-risk resected cutaneous melanoma. Eur J Cancer 34: S18-S21, 1998.

26. Eggermont AM, Suciu S, Santinami M, et al: Adjuvant therapy with pegylated interferon alfa- $2 b$ versus observation alone in resected stage III melanoma: final results of EORTC 18991, a randomised phase III trial. Lancet 372: 117-126, 2008.

27. Cheever MA and Higano CS: PROVENGE (Sipuleucel-T) in prostate cancer: the first FDA-approved therapeutic cancer vaccine. Clin Cancer Res 17: 3520-3526, 2011

28. Zikich D, Schachter J and Besser MJ: Immunotherapy for the management of advanced melanoma: the next steps. Am J Clin Dermatol 14: 261-272, 2013.

29. Dannull J, Haley NR, Archer G, et al: Melanoma immunotherapy using mature DCs expressing the constitutive proteasome. J Clin Invest 123: 3135-3145, 2013.

30. Yuan J, Ku GY, Gallardo HF, et al: Safety and immunogenicity of a human and mouse gp100 DNA vaccine in a phase I trial of patients with melanoma. Cancer Immun 9: 5, 2009.

31. Reichert JM and Dhimolea E: The future of antibodies as cancer drugs. Drug Discov Today 17: 954-963, 2012.

32. Azijli K, Stelloo E, Peters GJ and van den Eertwegh AJ: New developments in the treatment of metastatic melanoma: immune checkpoint inhibitors and targeted therapies. Anticancer Res 34: 1493-1505, 2014

33. Price MA, Colvin Wanshura LE, Yang J, et al: CSPG4, a potential therapeutic target, facilitates malignant progression of melanoma. Pigment Cell Melanoma Res 24: 1148-1157, 2011.

34. Wang X, Osada T, Wang Y, et al: CSPG4 protein as a new target for the antibody-based immunotherapy of triple-negative breast cancer. J Natl Cancer Inst 102: 1496-1512, 2010.

35. Yang J, Price MA, Neudauer CL, et al: Melanoma chondroitin sulfate proteoglycan enhances FAK and ERK activation by distinct mechanisms. J Cell Biol 165: 881-891, 2004.

36. Yang J, Price MA, Li GY, et al: Melanoma proteoglycan modifies gene expression to stimulate tumor cell motility, growth, and epithelial-to-mesenchymal transition. Cancer Res 69: 7538-7547, 2009.

37. Chekenya M, Krakstad C, Svendsen A, et al: The progenitor cell marker NG2/MPG promotes chemoresistance by activation of integrin-dependent PI3K/Akt signaling. Oncogene 27: 5182-5194, 2008 .

38. Maciag PC, Seavey MM, Pan ZK, Ferrone S and Paterson Y: Cancer immunotherapy targeting the high molecular weight melanoma-associated antigen protein results in a broad antitumor response and reduction of pericytes in the tumor vasculature. Cancer Res 68: 8066-8075, 2008.

39. Kusama M, Kageshita T, Chen ZJ and Ferrone S: Characterization of syngeneic antiidiotypic monoclonal antibodies to murine anti-human high molecular weight melanoma-associated antigen monoclonal antibodies. J Immunol 143: 3844-3852, 1989.

40. Chen ZJ, Yang H, Kageshita T and Ferrone S: Human highmolecular-weight melanoma-associated antigen mimicry by mouse antiidiotypic monoclonal antibody TK7-371. Cancer Res 51: 4790-4797, 1991

41. Mittelman A, Chen ZJ, Yang H, Wong GY and Ferrone S: Human high molecular weight melanoma-associated antigen (HMW-MAA) mimicry by mouse anti-idiotypic monoclonal antibody MK2-23: induction of humoral anti-HMW-MAA immunity and prolongation of survival in patients with stage IV melanoma. Proc Natl Acad Sci USA 89: 466-470, 1992.
42. Mittelman A, Chen GZ, Wong GY, Liu C, Hirai S and Ferrone S: Human high molecular weight-melanoma associated antigen mimicry by mouse anti-idiotypic monoclonal antibody MK2-23 modulation of the immunogenicity in patients with malignant melanoma. Clin Cancer Res 1: 705-713, 1995.

43. Mittelman A, Wang X, Matsumoto K and Ferrone S: Antiantiidiotypic response and clinical course of the disease in patients with malignant melanoma immunized with mouse antiidiotypic monoclonal antibody MK2-23. Hybridoma 14: 175-181, 1995.

44. Murray JL, Gillogly M, Kawano K, et al: Fine specificity of high molecular weight-melanoma-associated antigen-specific cytotoxic T lymphocytes elicited by anti-idiotypic monoclonal antibodies in patients with melanoma. Cancer Res 64: 5481-5488, 2004.

45. Torisu-Itakura H, Schoellhammer HF, Sim MS, et al: Redirected lysis of human melanoma cells by a MCSP/CD3-bispecific BiTE antibody that engages patient-derived T cells. J Immunother 34: 597-605, 2011.

46. Rybczynska AA, Dierckx RA, Ishiwata K, Elsinga PH and van Waarde A: Cytotoxicity of sigma-receptor ligands is associated with major changes of cellular metabolism and complete occupancy of the sigma-2 subpopulation. J Nucl Med 49: 2049-2056, 2008.

47. de Bruyn M, Rybczynska AA, Wei Y, et al: Melanoma-associated Chondroitin Sulfate Proteoglycan (MCSP)-targeted delivery of soluble TRAIL potently inhibits melanoma outgrowth in vitro and in vivo. Mol Cancer 9: 301, 2010.

48. Geldres C, Savoldo B, Hoyos V, et al: T lymphocytes redirected against the chondroitin sulfate proteoglycan- 4 control the growth of multiple solid tumors both in vitro and in vivo. Clin Cancer Res 20: 962-971, 2014.

49. Mehnert JM, McCarthy MM, Jilaveanu L, et al: Quantitative expression of VEGF, VEGF-R1, VEGF-R2, and VEGF-R3 in melanoma tissue microarrays. Hum Pathol 41: 375-384, 2010.

50. Spinella F, Caprara V, Cianfrocca R, et al: The interplay between hypoxia, endothelial and melanoma cells regulates vascularization and cell motility through endothelin-1 and vascular endothelial growth factor. Carcinogenesis 35: 840-848, 2014.

51. Hsu JY and Wakelee HA: Monoclonal antibodies targeting vascular endothelial growth factor: current status and future challenges in cancer therapy. BioDrugs 23: 289-304, 2009.

52. Molhoek KR, Griesemann H, Shu J, Gershenwald JE, Brautigan DL and Slingluff CL Jr: Human melanoma cytolysis by combined inhibition of mammalian target of rapamycin and vascular endothelial growth factor/vascular endothelial growth factor receptor-2. Cancer Res 68: 4392-4397, 2008.

53. Del Vecchio M, Mortarini R, Canova S, et al: Bevacizumab plus fotemustine as first-line treatment in metastatic melanoma patients: clinical activity and modulation of angiogenesis and lymphangiogenesis factors. Clin Cancer Res 16: 5862-5872, 2010.

54. Varker KA, Biber JE, Kefauver C, et al: A randomized phase 2 trial of bevacizumab with or without daily low-dose interferon alfa-2b in metastatic malignant melanoma. Ann Surg Oncol 14: 2367-2376, 2007.

55. Guenterberg KD, Grignol VP, Relekar KV, et al: A pilot study of bevacizumab and interferon-alpha $2 \mathrm{~b}$ in ocular melanoma. Am J Clin Oncol 34: 87-91, 2011.

56. Corrie PG, Marshall A, Dunn JA, et al: Adjuvant bevacizumab in patients with melanoma at high risk of recurrence (AVAST-M): preplanned interim results from a multicentre, open-label, randomised controlled phase 3 study. Lancet Oncol 15: 620-630, 2014.

57. Shrimali RK, Yu Z, Theoret MR, Chinnasamy D, Restifo NP and Rosenberg SA: Antiangiogenic agents can increase lymphocyte infiltration into tumor and enhance the effectiveness of adoptive immunotherapy of cancer. Cancer Res 70: 6171-6180, 2010.

58. Perez DG, Suman VJ, Fitch TR, et al: Phase 2 trial of carboplatin, weekly paclitaxel, and biweekly bevacizumab in patients with unresectable stage IV melanoma: a North Central Cancer Treatment Group study, N047A. Cancer 115: 119-127, 2009.

59. Perez EA, Hillman DW, Dentchev T, et al: North Central Cancer Treatment Group (NCCTG) N0432: phase II trial of docetaxel with capecitabine and bevacizumab as first-line chemotherapy for patients with metastatic breast cancer. Ann Oncol 21: 269-274, 2010.

60. Allison JP, Chambers C, Hurwitz A, et al: A role for CTLA-4 mediated inhibitory signals in peripheral $\mathrm{T}$ cell tolerance? Novartis Found Symp 215: 92-98, 1998. 
61. Linsley PS, Brady W, Urnes M, Grosmaire LS, Damle NK and Ledbetter JA: CTLA-4 is a second receptor for the B cell activation antigen B7. J Exp Med 174: 561-569, 1991.

62. Simpson TR, Li F, Montalvo-Ortiz W, et al: Fc-dependent depletion of tumor-infiltrating regulatory $\mathrm{T}$ cells co-defines the efficacy of anti-CTLA-4 therapy against melanoma. J Exp Med 210: 1695-1710, 2013

63. Bulliard Y, Jolicoeur R, Windman M, et al: Activating Fc $\gamma$ receptors contribute to the antitumor activities of immunoregulatory receptor-targeting antibodies. J Exp Med 210: 1685-1693, 2013.

64. Friedline RH, Brown DS, Nguyen $\mathrm{H}$, et al: $\mathrm{CD} 4^{+}$regulatory $\mathrm{T}$ cells require CTLA- 4 for the maintenance of systemic tolerance. J Exp Med 206: 421-434, 2009.

65. Phan GQ, Yang JC, Sherry RM, et al: Cancer regression and autoimmunity induced by cytotoxic T lymphocyte-associated antigen 4 blockade in patients with metastatic melanoma. Proc Natl Acad Sci USA 100: 8372-8377, 2003.

66. Weber JS, O'Day S, Urba W, et al: Phase I/II study of ipilimumab for patients with metastatic melanoma. J Clin Oncol 26 5950-5956, 2008.

67. Ribas A, Camacho LH, Lopez-Berestein G, et al: Antitumor activity in melanoma and anti-self responses in a phase I trial with the anti-cytotoxic T lymphocyte-associated antigen 4 monoclonal antibody CP-675,206. J Clin Oncol 23: 8968-8977, 2005.

68. Robert C, Thomas L, Bondarenko I, et al: Ipilimumab plus dacarbazine for previously untreated metastatic melanoma. N Engl J Med 364: 2517-2526, 2011.

69. Hersh EM, O'Day SJ, Powderly J, et al: A phase II multicenter study of ipilimumab with or without dacarbazine in chemotherapy-naive patients with advanced melanoma. Invest New Drugs 29: 489-498, 2011

70. Hodi FS, O'Day SJ, McDermott DF, et al: Improved survival with ipilimumab in patients with metastatic melanoma. New Engl J Med 363: 711-723, 2010.

71. Callahan MK, Postow MA and Wolchok JD: Immunomodulatory therapy for melanoma: ipilimumab and beyond. Clin Dermatol 31: 191-199, 2013.

72. Postow MA, Callahan MK and Wolchok JD: The antitumor immunity of ipilimumab: (T-cell) memories to last a lifetime? Clin Cancer Res 18: 1821-1823, 2012.

73. Della Vittoria Scarpati G, Fusciello C, Perri F, et al: Ipilimumab in the treatment of metastatic melanoma: management of adverse events. Onco Targets Ther 7: 203-209, 2014.

74. Ribas A, Kefford R, Marshall MA, et al: Phase III randomized clinical trial comparing tremelimumab with standard-of-care chemotherapy in patients with advanced melanoma. J Clin Oncol 31: 616-622, 2013

75. Iwai Y, Ishida M, Tanaka Y, Okazaki T, Honjo T and Minato N: Involvement of PD-L1 on tumor cells in the escape from host immune system and tumor immunotherapy by PD-L1 blockade. Proc Natl Acad Sci USA 99: 12293-12297, 2002.

76. Hino R, Kabashima K, Kato Y, et al: Tumor cell expression of programmed cell death-1 ligand 1 is a prognostic factor for malignant melanoma. Cancer 116: 1757-1766, 2010.

77. Ahmadzadeh M, Johnson LA, Heemskerk B, et al: Tumor antigen-specific CD8 T cells infiltrating the tumor express high levels of PD-1 and are functionally impaired. Blood 114: $1537-1544,2009$

78. Brahmer JR, Drake CG, Wollner I, et al: Phase I study of single-agent anti-programmed death-1 (MDX-1106) in refractory solid tumors: safety, clinical activity, pharmacodynamics, and immunologic correlates. J Clin Oncol 28: 3167-3175, 2010.

79. Topalian SL, Sznol M, McDermott DF, et al: Survival, durable tumor remission, and long-term safety in patients with advanced melanoma receiving nivolumab. J Clin Oncol 32: 1020-1030, 2014.

80. Lipson EJ, Sharfman WH, Drake CG, et al: Durable cancer regression off-treatment and effective reinduction therapy with an anti-PD-1 antibody. Clin Cancer Res 19: 462-468, 2013

81. Hamid O, Robert C, Daud A, et al: Safety and tumor responses with lambrolizumab (anti-PD-1) in melanoma. New Engl J Med 369: 134-144, 2013.

82. Brahmer JR, Tykodi SS, Chow LQ, et al: Safety and activity of anti-PD-L1 antibody in patients with advanced cancer. New Engl J Med 366: 2455-2465, 2012

83. Yao X, Ahmadzadeh M, Lu YC, et al: Levels of peripheral $\mathrm{CD} 4(+)$ FoxP3(+) regulatory $\mathrm{T}$ cells are negatively associated with clinical response to adoptive immunotherapy of human cancer. Blood 119: 5688-5696, 2012.
84. De Panfilis G, Campanini N, Santini M, et al: Phase- and stage-related proportions of $\mathrm{T}$ cells bearing the transcription factor FOXP3 infiltrate primary melanoma. J Invest Dermatol 128: 676-684, 2008.

85. Miracco C, Mourmouras V, Biagioli M, et al: Utility of tumourinfiltrating $\mathrm{CD} 25^{+} \mathrm{FOXP} 3^{+}$regulatory $\mathrm{T}$ cell evaluation in predicting local recurrence in vertical growth phase cutaneous melanoma. Oncol Rep 18: 1115-1122, 2007.

86. Agius E, Lacy KE, Vukmanovic-Stejic M, et al: Decreased TNF-alpha synthesis by macrophages restricts cutaneous immunosurveillance by memory $\mathrm{CD} 4^{+} \mathrm{T}$ cells during aging. J Exp Med 206: 1929-1940, 2009.

87. Jacobs JF, Punt CJ, Lesterhuis WJ, et al: Dendritic cell vaccination in combination with anti-CD25 monoclonal antibody treatment: a phase III study in metastatic melanoma patients. Clin Cancer Res 16: 5067-5078, 2010.

88. Curran MA, Montalvo W, Yagita H and Allison JP: PD-1 and CTLA-4 combination blockade expands infiltrating T cells and reduces regulatory $\mathrm{T}$ and myeloid cells within $\mathrm{B} 16$ melanoma tumors. Proc Natl Acad Sci USA 107: 4275-4280, 2010.

89. Wolchok JD, Kluger H, Callahan MK, et al: Nivolumab plus ipilimumab in advanced melanoma. New Engl J Med 369 122-133, 2013

90. Ly LV, Sluijter M, van der Burg SH, Jager MJ and van Hall T: Effective cooperation of monoclonal antibody and peptide vaccine for the treatment of mouse melanoma. J Immunol 190: 489-496, 2013.

91. Alderson KL, Luangrath M, Elsenheimer MM, et al: Enhancement of the anti-melanoma response of Hu14.18K322A by $\alpha \mathrm{CD} 40+\mathrm{CpG}$. Cancer Immunol Immunother 62: 665-675, 2013.

92. Flaherty KT: Dividing and conquering: controlling advanced melanoma by targeting oncogene-defined subsets. Clin Exp Metastasis 29: 841-846, 2012

93. Chapman PB, Hauschild A, Robert C, et al: Updated overall survival (OS) results for BRIM-3, a phase III randomized, open-label, multicenter trial comparing BRAF inhibitor vemurafenib (vem) with dacarbazine (DTIC) in previously untreated patients with BRAFV600E-mutated melanoma. J Clin Oncol: 8502, 2012.

94. Hauschild A, Grob JJ, Demidov LV, et al: Dabrafenib in BRAF-mutated metastatic melanoma: a multicentre, open-label, phase 3 randomised controlled trial. Lancet 380: 358-365, 2012.

95. Knight DA, Ngiow SF, Li M, et al: Host immunity contributes to the anti-melanoma activity of BRAF inhibitors. J Clin Invest 123: 1371-1381, 2013.

96. Ngiow SF, Knight DA, Ribas A, McArthur GA and Smyth MJ: BRAF-targeted therapy and immune responses to melanoma. Oncoimmunology 2: e24462, 2013.

97. Ascierto PA, Simeone E, Giannarelli D, Grimaldi AM Romano A and Mozzillo N: Sequencing of BRAF inhibitors and ipilimumab in patients with metastatic melanoma: a possible algorithm for clinical use. J Transl Med 10: 107, 2012.

98. Ribas A, Hodi FS, Callahan M, Konto C and Wolchok J: Hepatotoxicity with combination of vemurafenib and ipilimumab. N Engl J Med 368: 1365-1366, 2013.

99. Culos KA and Cuellar S: Novel targets in the treatment of advanced melanoma: new first-line treatment options. Ann Pharmacother 47: 519-526, 2013.

100. Woof JM: Insights from Fc receptor biology: a route to improved antibody reagents. MAbs 4: 291-293, 2012.

101. Bossi G, Buisson S, Oates J, Jakobsen BK and Hassan NJ: ImmTAC-redirected tumour cell killing induces and potentiates antigen cross-presentation by dendritic cells. Cancer Immunol Immunother 63: 437-448, 2014.

102. McCormack E, Adams KJ, Hassan NJ, et al: Bi-specific TCR-anti CD3 redirected T-cell targeting of NY-ESO-1- and LAGE-1-positive tumors. Cancer Immunol Immunother 62: 773-785, 2013

103. Karagiannis SN, Josephs DH, Karagiannis P, et al: Recombinant $\operatorname{IgE}$ antibodies for passive immunotherapy of solid tumours: from concept towards clinical application. Cancer Immunol Immunother 61: 1547-1564, 2012.

104. Josephs DH, Spicer JF, Karagiannis P, Gould HJ and Karagiannis SN: IgE immunotherapy: a novel concept with promise for the treatment of cancer. MAbs 6: 54-72, 2014.

105. Boross P, Lohse S, Nederend M, et al: IgA EGFR antibodies mediate tumour killing in vivo. EMBO Mol Med 5: 1213-1226, 2013. 
106.Lohse S, Brunke C, Derer S, et al: Characterization of a mutated IgA2 antibody of the m(1) allotype against the epidermal growth factor receptor for the recruitment of monocytes and macrophages. J Biol Chem 287: 25139-25150, 2012.

107.Lohse S, Derer S, Beyer T, et al: Recombinant dimeric IgA antibodies against the epidermal growth factor receptor mediate effective tumor cell killing. J Immunol 186: 3770-3778, 2011.

108.Peggs KS, Quezada SA, Chambers CA, Korman AJ and Allison JP: Blockade of CTLA-4 on both effector and regulatory T cell compartments contributes to the antitumor activity of antiCTLA-4 antibodies. J Exp Med 206: 1717-1725, 2009.
109. Silina K, Rulle U, Kalnina Z and Line A: Manipulation of tumour-infiltrating $\mathrm{B}$ cells and tertiary lymphoid structures: a novel anti-cancer treatment avenue? Cancer Immunol Immunother: Apr 3, 2014 (Epub ahead of print).

110. Cipponi A, Wieers G, van Baren N and Coulie PG: Tumorinfiltrating lymphocytes: apparently good for melanoma patients. But why? Cancer Immunol Immunother 60: 1153-1160, 2011.

111. Tsoka S, Ainali C, Karagiannis P, et al: Toward prediction of immune mechanisms and design of immunotherapies in melanoma. Crit Rev Biomed Eng 40: 279-294, 2012. 